\title{
Peningkatan Hasil Belajar IPS Materi Aktivitas Manusia dalam Memenuhi Kebutuhan Melalui Model Pembelajaran Jigsaw pada Siswa Kelas VII Semester II Tahun Pelajaran 2017/2018 di SMP Negeri 2 Gandusari Trenggalek
}

\author{
Supraptani ${ }^{(1)}$ \\ ${ }^{1}$ SMP Negeri 2 Gandusari Kabupaten Trenggalek, Propinsi Jawa Timur. \\ Email: 1suprap_tini@gmail.com \\ DOI: https://doi.org/10.28926/riset_konseptual.v2i4.78
}

\begin{abstract}
ABSTRAK
Pendidikan di sekolah dapat menunjang proses pertumbuhan dan pengembangan potensi yang ada pada peserta didik agar mampu menjalankan tugas-tugas kehidupan sebagai individu maupun sebagai anggota masyarakat. Kenyataan di lapangan siswa susah memahami pelajaran IPS alasanya dikarenakan pembelajaran yang monoton, lebih banyak hafalan, guru mendominasi kegiatan pembelajaran dengan lebih banyak kegiatan ceramah sehingga siswa menjadi pasif, kadang-kadang menggunakan metode diskusi biasa, yang aktif hanya siswa yang pintar saja, yang lain lebih banyak diam atau melakukan kesibukan sendiri. Tujuan penelitian ini untuk mendiskripsikan peningkatan hasil belajar ips materi aktivitas manusia dalam memenuhi kebutuhan melalui model pembelajaran jigsaw pada siswa kelas vii semester ii tahun pelajaran 2017/ 2018 di SMP Negeri 2 Gandusari Trenggalek. Berdasar hasil penelitian tindakan kelas, pada Siklus I kebanyakan siswa belum berani mengemukakan pendapat sehingga banyak waktu yang terbuang. Siswa kurang berani memberikan masukan terkait dengan pokok masalah dalam Materi Aktivitas Manusia Dalam Memenuhi Kebutuhan. Kebanyakan siswa menunggu dan bergantung kepada siswa lain yang dianggap memiliki kelebihan dalam kepandaian daripada dirinya. Akan tetapi pada Siklus II, siswa sudah berani mengemukakan pendapat. Siswa berebut kesempatan untuk menyampaikan hasil kerjanya tentang topik Materi Aktivitas Manusia Dalam Memenuhi Kebutuhan. Demikian halnya dengan saat mengomentari presentasi temannya.
\end{abstract}

Kata kunci: ips, aktivitas manusia dalam memenuhi kebutuhan, jigsaw

\section{PENDAHULUAN}

Sekolah sebagai lembaga pendidikan yang menyelenggarakan proses belajar mengajar, memegang peranan penting dalam rangka pembentukan sikap, pengetahuan serta budi pekerti. Tujuan pembelajaran ilmu pendidikan sosial (IPS) adalah untuk mempersiapkan siswa menjadi warga negara yang baik dalam kehidupannya di masyarakat.

Kenyataan di lapangan siswa susah memahami pelajaran IPS alasanya dikarenakan pembelajaran yang monoton, lebih banyak hafalan, guru mendominasi kegiatan pembelajaran dengan lebih banyak kegiatan ceramah sehingga siswa menjadi pasif, kadang-kadang menggunakan metode diskusi biasa, yang aktif hanya siswa yang pintar saja, yang lain lebih banyak diam atau melakukan kesibukan sendiri.

Berdasarkan observasi awal yang dilakukan peneliti di kelas VII Smp Negeri 2 Gandusari Trenggalek, hasil belajar IPS tergolong rendah, dapat disimpulkan guru masih menjadi sumber belajar yang utama, guru banyak mnggunakan metode konvensional ceramah, sehingga siswa hanya pasif saat pelajaran IPS. Dari hasil yang diperoleh tersebut perlu dicarikan solusi agara proses belajar mengajar bias lebih maksimal, dan tujuan belajar dapat tercapai. Tujuan belajar adalah: a) Untuk mendapatkan pengetahuan; b) Penanaman konsep dan keterampilan; c) Pembentukan sikap (Sudirman, 2011: 25). 
Vol. 2 No. 4, Oktober 2018;

Pembelajaran kooperatif adalah salah satu bentuk pembelajaran yang berdasarkan pemahaman konstruktivis. Pembelajaran kooperatif merupakan strategi belajar dengan sejumlah siswa sebagai anggota kelompok kecil yang tingkat kemampuannya berbeda. Dalam menyelesaikan tugas kelompoknya, setiap siswa anggota kelompok harus saling bekerja sama dan saling membantu untuk memahami materi pelajaran. Pembelajaran kooperatif adalah pembelajaran yang secara sadar dan sengaja mengembangkan interaksi saling asuh antarsiswa untuk menghindari ketersinggungan dan kesalahpahaman yang dapat menimbulkan permusuhan (Kunandar, 2011: 363). Diharapkan dengan pembelajaran kooperatif akan muncul generasi baru yang memiliki prestasi akademik yang cemerlang dan memiliki solidaritas sosial yang kuat.

Mendiskripsikan Peningkatan Hasil Belajar Ips Materi Aktivitas Manusia Dalam Memenuhi Kebutuhan Melalui Model Pembelajaran Jigsaw Pada Siswa Kelas VII Semester II Tahun Pelajaran 2017/ 2018 di SMP Negeri 2 Gandusari Trenggalek.

\section{METODE}

Penelitian ini dilaksanakan dalam dua siklus. Tiap siklus dilaksanakan dua kali pertemuan. Setiap pertemuan selama dua jam pelajaran. Masing-masing siklus terdiri atas tiga tahap, yaitu (1) tahap perencanaan. (2) tahap pelaksanaan dan pengamatan, dan (3) tahap refleksi (Kemmis \& Mc Taggart, dalam modul guru pembelajar 1997: 18).

Siklus I dilaksanakan dalam empat tahap, yaitu (1) tahap perencanaan. (2) tahap pelaksanaan atau tindakan, (3) tahap pengamatan atau observasi, dan (4) tahap refleksi. Siklus satu bertujuan untuk mengetahui bagaimana peningkatan pembelajaran IPS materi aktivitas manusia dalam memenuhi kebutuhan menggunakan model Jigsaw. Adapun masing-masing tahap seperti berikut ini.

Pada tahap perencanaan ini kegiatan yang dilakukan adalah mempersiapkan beberapa perangkat yang berkenaan dengan kegiatan penelitian. Penyusunan rencana pelaksanaan pembelajaran IPS materi aktivitas manusia dalam memenuhi kebutuhan dengan model "jigsaw". Penyusunan lembar kerja siswa yang memuat tugas yang berkaitan dengan IPS materi aktivitas manusia dalam memenuhi kebutuhan dengan model "jigsaw". Penyusunan angket siswa yang berupa pertanyaan yang harus jawab oleh siswa pada kolom yang sudah disediakan. Penyusunan lembar observasi yang berisi pertanyaan yang harus jawab oleh siswa pada kolom yang sudah disediakan dengan penilaian, baik, cukup, atau kurang, sangat kurang. Penyusunan observasi terhadap kegiatan guru yang akan dilakukan oleh kolaborator. observasi kegiatan guru menggunakan teknik pengamatan dan dokumentasi saat melakukan pembelajaran.

Alokasi waktu tahap pelaksanaan penelitian tindakan kelas pada pra siklus hari kamis tanggal 15 dan sabtu 17 februari 2018. Siklus I adalah empat jam pelajaran yang akan dilaksanakan pada hari kamis 22 dan sabtu 24 februari 2018. Siklus II dilaksanakan hari kamis tanggal 1 dan sabtu tanggal 3 maret 2018. Kegiatan yang dilakukan pada tahap ini berupa pelaksanaan pembelajaran teknik "Jigsaw" dengan langkah-langkah sebagai berikut.

Pertemuan I, (1) Siswa mendapat penjelasan dari guru tentang kompetensi dasar dan tujuan pembelajaran yang terkait dengan materi aktivitas manusia dalam memenuhi kebutuhan. (2) Siswa secara kelompok ditugasi untuk mencermati yang terkait dengan materi aktivitas manusia dalam memenuhi kebutuhan. (3) Masingmasing siswa mencari dan menemukan hal-hal yang berhubungan dengan materi aktivitas manusia dalam memenuhi kebutuhan (lihat LKS). (4) Siswa berdiskusi tentang tugas yang sudah dibuat. (5) Tiga kelompok diminta mempresentasikan hasil kerjanya di depan kelas siswa yang lain memperhatikan. (6) Kelompok yang lain memberikan tanggapan terhadap presentasi telah dilakukan temannya. (7) Kelompok yang tampil diberi kesempatan untuk memberikan komentar terhadap tanggapan dari teman tersebut.

Pertemuan II, (1) Siswa secara individu ditugasi untuk mencermati yang terkait dengan materi aktivitas manusia dalam memenuhi kebutuhan. (2) Masing- 
masing siswa mencari dan menemukan hal-hal yang berhubungan dengan materi aktivitas manusia dalam memenuhi kebutuhan (lihat LKS). (3) Siswa berdiskusi tentang tugas yang sudah dibuat. (4) Tiga kelompok diminta mempresentasikan hasil kerjanya di depan kelas siswa yang lain memperhatikan. (5) Kelompok yang lain memberikan tanggapan terhadap presentasi telah dilakukan temannya. (6) Kelompok yang tampil diberi kesempatan untuk memberikan komentar terhadap tanggapan dari teman tersebut. (7) Siswa mengerjakan soal pembelajaran IPS materi aktivitas manusia dalam memenuhi kebutuhan, yang sudah ada pada LKS.

Pengamatan kegiatan pembelajaran IPS materi aktivitas manusia dalam memenuhi kebutuhan, menggunakan model Jigsaw. Dilaksanakan pada proses pembelajaran untuk kegiatan inti pertemuan 1 yaitu langkah ke-1 sampai dengan langkah ke-7 dan kegiatan inti pertemuan 2 yaitu langkah ke-1 sampai dengan langkah ke-7 berdasarkan Rencana Pelaksanaan Pembelajaran (lihat Lampiran 1). Pengamatan dilakukan oleh kolaborator dengan menggunakan dokumentasi berupa foto dan data. Unsur yang diamati meliputi kerja sama dalam kelompok, mengungkapkan dan menerima pendapat, serta keaktifan siswa selama berlangsungnya proses pembelajaran. Di samping itu juga diamati kegiatan guru selama proses pembelajaran terkait dengan keterlaksanaan urut-urutan pelaksanaan pembelajaran.

\section{HASIL}

Hasil test pra siklus hari kamis tanggal 15 dan sabtu 17 februari 2018, siswa tentang aktivitas manusia dalam memenuhi kebutuhan menggunakan dengan pokok permasalahan yang berkenaan dengan kegiatan sekolah pada pra siklus diperoleh nilai tingkat penguasaan siswa dapat dirinci seperti berikut ini. 1) Siswa yang memiliki tingkat penguasaan 90 - 100\% tidak ada, 2) Siswa dengan tingkat penguasaan 80 $89 \%$ tidak ada. Siswa dengan tingkat penguasaan $70-79 \%$ sebanyak 4 anak, 4) Siswa dengan tingkat penguasaan 60-69\% sebanyak 13 anak, dan 5) Siswa dengan penguasaan 50-59\% sebanyak 12 anak. Dari paparan tersebut dapat disimpulkan penguasaan materi siswa pada pra siklus belum berhasil karena tingkat penguasaan secara klasikal belum terpenuhi.

Perencanaan Penelitian Tindakan Kelas Siklus I ini dilaksanakan di SMP Negeri 2 Gandusari pada hari kamis 22 dan sabtu 24 februari 2018. Kegiatan pada tahap perencanaan ini meliputi menyusun silabus. rencana pembelajaran, lembar kegiatan siswa, angket siswa, panduan observasi kegiatan siswa dan panduan observasi kegiatan guru. Perencanaan Pembelajaran terdiri atas silabus untuk satu kompetensi dasar beserta rencana pelaksanaan pembelajaran (RPP). Perencanaan Pembelajaran dikaitkan dengan materi aktivitas manusia dalam memenuhi kebutuhan. Rencana Pelaksanaan Pembelajaran merupakan pedoman untuk melaksanakan proses pembelajaran di kelas. Oleh karena itu, Rencana Pelaksanaan Pembelajaran harus menggambarkan proses pembelajaran secara rinci dan memuat pengalaman belajar yang seharusnya dimiliki oleh siswa.

Pelaksanaan penelitian di SMP Negeri 2 Gandusari pada siklus I pada hari kamis 22 dan sabtu 24 februari 2018. Adapun langkah-langkah pada pelaksanaan ini adalah: (a) Guru menyampaikan salam dan mempersilakan siswa berdoa. (b) Guru mendata kehadiran siswa, dengan menanyakan siswa yang tidak masuk. (c)Guru menyampaikan kompetensi dasar dan tujuan pembelajaran. (d)Guru memberikan apersepsi dan motivasi kepada siswa tentang materi yang akan dibahas dan pentingnya materi untuk kehidupan sehari-hari. (e)Siswa mendapat penjelasan dari guru tentang kompetensi dasar dan tujuan pembelajaran yang terkait dengan materi aktivitas manusia dalam memenuhi kebutuhan. (f)Siswa secara kelompok ditugasi untuk mencermati yang terkait dengan materi aktivitas manusia dalam memenuhi kebutuhan. (g)Masing-masing siswa mencari dan menemukan hal-hal yang berhubungan dengan materi aktivitas manusia dalam memenuhi kebutuhan (lihat LKS). (h)Siswa berdiskusi tentang tugas yang sudah dibuat. (i)Tiga kelompok diminta 
mempresentasikan hasil kerjanya di depan kelas siswa yang lain memperhatikan. (j)Kelompok yang lain memberikan tanggapan terhadap presentasi telah dilakukan temannya. (k)Kelompok yang tampil diberi kesempatan untuk memberikan komentar terhadap tanggapan dari teman tersebut. (I) Guru menjadi penengah saat diskusi. (m) Guru menugaskan siswa untuk belajar tentang materi yang sudah didiskusikan.

Pada saat diskusi untuk menentukan pokok permasalahan aktivitas manusia dalam memenuhi kebutuhan berlangsung, masih ada beberapa siswa yang bercanda dengan teman satu bangkunya. Kehadiran guru kolaborator yang membantu melakukan penelitian dan duduk di bangku belakang. Pengamatan pelaksanaan tindakan dibagi dalam 2 (dua) bagian yaitu pengamatan terhadap siswa dan terhadap guru (peneliti) oleh kolaborator.

(a)Pengamatan Kegiatan Siswa, (1)Pada awal pelaksanaan siswa merasa terganggu/tidak nyaman dalam belajar karena adanya guru kolaborator.(2)Pada saat mulai materi aktivitas manusia dalam memenuhi kebutuhan beberapa siswa merasa senang karena dapat memecahkan permasalahan. (3)Pada saat itu pula ada siswa yang acuh tak acuh, ramai. Siswa-siswa ini kurang dapat menyesuaikan diri. Di samping itu mereka tidak memiliki motivasi belajar materi aktivitas manusia dalam memenuhi kebutuhan. (4)Siswa berdiskusi tentang materi IPS aktivitas manusia dalam memenuhi kebutuhan. Dan guru sebagai penengah. (5)Hasil Evaluasi disimpulkan hasil dari evaluasi siswa siklus I. Tingkat penguasaan siswa dapat dirinci seperti berikut ini. 1) Siswa yang memiliki tingkat penguasaan $90-100 \%$ tidak ada, 2) Siswa dengan tingkat penguasaan $80-89 \%$ sebanyak 2 anak. Siswa dengan tingkat penguasaan 70 - 79\% sebanyak 8 anak, 4) Siswa dengan tingkat penguasaan 60$69 \%$ sebanyak 13 anak, dan 5) Siswa dengan penguasaan 50-59\% sebanyak 6 anak. Dari paparan tersebut dapat disimpulkan penguasaan materi siswa pada siklus I belum berhasil karena tingkat penguasaan secara klasikal belum terpenuhi. (6)Observasi kegiatan siswa dilakukan oleh kolaborator sudah berjalan baik. Untuk meningkatkan aktivitas siswa pada siklus I ini diberikan penghargaan kepada siswa yang secara aktif mengikuti pembelajaran dengan cara diumumkan siswa teraktif 1, 2, dan 3 . Adapun siswa teraktif pada Siklus 1 ini adalah teraktif 1 Dini Marantika, teraktif 2 Putri Septianingsih, teraktif 3 Enggrit Ferdian Saputra.

(b) Pengamatan Kegiatan Guru (Peneliti), Pengamatan terhadap guru dilakukan oleh kolaborator bahwa guru telah melaksanakan pembelajaran dengan baik sesuai dengan Rencana Pelaksanaan Pembelajaran. Pada saat membuat penguatan materi pada siklus I ini peran guru masih terlalu dominan, seharusnya guru hanya sebagai fasilitator saja dan penengah saja. Dengan demikian penegasan materi itu belum benar-benar murni hasil pemikiran siswa.

Refleksi Berdasarkan hasil diskusi bersama kolaborator serta hasil evaluasi yang dilakukan dapat disimpulkan sebagai berikut: (a)Skenario pembelajaran dapat berlangsung sesuai yang diharapkan dan dapat dipakai siklus berikutnya. (b)Diskusi siswa belum terlaksana secara maksimal karena masih ada siswa yang kurang aktif dalam berdiskusi sehingga perlu adanya motivasi. (b)Siswa yang tuntas belajar secara individu ada 17 anak (58,62\%), secara klasikal belum tuntas, dan dilanjutkan ke siklus II. (d)Untuk guru dalam membentuk situasi belajar kurang santai, terlalu terburu-buru dan terlalu serius/tegang sehingga siswa merasa kurang nyaman dalam belajar. Suasana kelas menjadi kurang kondusif untuk para siswa.

Guru selaku peneliti telah melaksanakan pembelajaran sesuai dengan Rencana Pelaksanaan Pembelajaran. Guru senantiasa memfasilitasi pembelajaran siswa dengan cara berkeliling dari satu siswa menuju siswa lain. Ketika mendatangi siswa selalu menanyakan kesulitan yang dialami oleh siswa tersebut. Apabila ada siswa yang bertanya lagi, guru pun mendatangi siswa tersebut. Secara prinsip siswa berdiskusi dengan sungguh-sungguh. Akan tetapi masih ada siswa yang belum serius dan masih bercanda. Hasil belajar siswa pada Siklus I ini kurang karena belum mencapai ketuntasan minimal secara klasikal. Siswa yang tuntas belajar 17 anak $(58,62 \%)$, Ketuntasan belum mencapai minimal $80 \%$. Tanggapan siswa terhadap 
Vol. 2 No. 4, Oktober 2018;

pelaksanaan pembelajaran rata-rata cukup. Pelaksanaan pembelajaran perlu ditingkatkan agar terjadi pembelajaran yang aktif, kreatif, efektif, dan menyenangkan.

Pembelajaran pada Siklus I belum berhasil karena ketuntasan klasikal minimal belum tercapai. Hal itu disebabkan oleh dua faktor yaitu pembelajaran belum sesuai dengan rencana dan kurangnya partsipasi siswa dalam proses pembelajaran. Oleh karena itu penelitian ini perlu dilanjutkan ke Siklus II.

Siklus II Perencanaan Penelitian Tindakan Kelas Siklus II ini dilaksanakan di SMP Negeri 2 Gandusari pada hari kamis 1 dan sabtu 3 maret 2018. Perencanaan tersebut berkenaan dengan standar kompetensi mengungkapkan materi aktivitas manusia dalam memenuhi kebutuhan menggunakan model Jigsaw. Berdasarkan hasil pengamatan Siklus I belum berjalan dengan baik dan lancar karena masih ada siswa yang bergurau. Untuk itu diharapkan pada siklus II nanti tidak ada lagi siswa yang bergurau saja. Pada Siklus II ini juga diberikan penghargaan kepada siswa yang mengikuti pembelajaran secara aktif dengan cara mengumumkan siswa teraktif 1,2 , dan 3.

Pelaksanaan penelitian di SMP Negeri 2 Gandusari pada siklus II hari kamis 1 dan sabtu 3 maret 2018. Adapun langkah-langkah pada pelaksanaan ini adalah: (a)Guru menyampaikan salam dan mempersilakan siswa berdoa. (b)Guru mendata kehadiran siswa, dengan menanyakan siswa yang tidak masuk. (c)Guru menyampaikan kompetensi dasar dan tujuan pembelajaran. (d)Guru memberikan apersepsi dan motivasi kepada siswa tentang materi yang akan dibahas dan pentingnya materi untuk kehidupan sehari-hari. (e)Siswa mendapat penjelasan dari guru tentang kompetensi dasar dan tujuan pembelajaran yang terkait dengan materi aktivitas manusia dalam memenuhi kebutuhan. (f)Siswa secara kelompok ditugasi untuk mencermati yang terkait dengan materi aktivitas manusia dalam memenuhi kebutuhan. (g)Masing-masing siswa mencari dan menemukan hal-hal yang berhubungan dengan materi aktivitas manusia dalam memenuhi kebutuhan (lihat LKS). (h)Siswa berdiskusi tentang tugas yang sudah dibuat. (i)Tiga kelompok diminta mempresentasikan hasil kerjanya di depan kelas siswa yang lain memperhatikan. (j)Kelompok yang lain memberikan tanggapan terhadap presentasi telah dilakukan temannya. (k)Kelompok yang tampil diberi kesempatan untuk memberikan komentar terhadap tanggapan dari teman tersebut. (I)Guru menjadi penengah saat diskusi. (m)Guru memberikan penghargaan pada siswa yang mendapatkan nilai terbaik.

Pengamatan pelaksanaan tindakan dibagi dalam 2 (dua) bagian yaitu pengamatan terhadap siswa dan terhadap guru (peneliti) oleh kolaborator.

Pengamatan Kegiatan Siswa, (a) Pada awal pelaksanaan siswa merasa nyaman dalam belajar dengan guru kolaborator. (b)Pada saat mulai materi aktivitas manusia dalam memenuhi kebutuhan beberapa semua siswa merasa senang karena dapat memecahkan permasalahan. (c)Siswa berdiskusi tentang materi IPS aktivitas manusia dalam memenuhi kebutuhan. Dan guru sebagai penengah. (d)Hasil Evaluasi disimpulkan hasil dari evaluasi siswa siklus II. Tingkat penguasaan siswa dapat dirinci seperti berikut ini. 1) Siswa yang memiliki tingkat penguasaan $90-100 \% 2$ anak, 2) Siswa dengan tingkat penguasaan 80 - 89\% sebanyak 3 anak. Siswa dengan tingkat penguasaan $70-79 \%$ sebanyak 13 anak, 4) Siswa dengan tingkat penguasaan 60$69 \%$ sebanyak 10 anak, dan 5) Siswa dengan penguasaan $50-59 \%$ sebanyak 1 anak. Dari paparan tersebut dapat disimpulkan penguasaan materi siswa pada siklus II berhasil karena tingkat penguasaan secara klasikal sudah terpenuhi.

Observasi kegiatan siswa dilakukan oleh kolaborator sudah berjalan sangat baik. Untuk itu siswa pada siklus II ini diberikan penghargaan kepada siswa yang secara aktif mengikuti pembelajaran dengan cara diumumkan siswa teraktif 1, 2, dan 3 . Adapun siswa teraktif pada Siklus II ini adalah teraktif 1 Dini Marantika, teraktif 2 Putri Septianingsih, teraktif 3 Muhammad Syahrul Ikromi.

Pengamatan terhadap guru dilakukan oleh kolaborator bahwa guru telah melaksanakan pembelajaran dengan sangat baik sesuai dengan Rencana Pelaksanaan Pembelajaran. Pada saat membuat penegasan pokok permasalahan 
untuk bahan menulis surat dinas Siklus II ini peran guru benar-benar sebagai fasilitator dan motivator. Dengan demikian topik dan pilihan kata itu benar-benar hasil pemikiran siswa.

Refleksi berdasarkan hasil diskusi bersama kolaborator serta hasil evaluasi yang dilakukan dapat disimpulkan sebagai berikut: (a)Skenario pembelajaran dapat berlangsung sesuai yang diharapkan. (b)Diskusi siswa terlaksana secara maksimal. (c) Siswa yang tuntas belajar secara individu ada 25 anak (86,26\%), secara klasikal tuntas.

\section{PEMBAHASAN}

Keberhasilan pembelajaran IPS Materi Aktivitas Manusia Dalam Memenuhi Kebutuhan dan sumber belajar kegiatan sekolah sudah baik. Keberhasilan siswa tersebut didasarkan pada hasil pengamatan terhadap berlangsungnya proses pembelajaran yang berkenaan dengan kegiatan guru maupun kegiatan siswa. Di samping itu, juga dapat diketahui dari penilaian. Keberhasilan tersebut dapat diketahui dari adanya peningkatan nilai. Pening-katan nilai dapat diketahui dengan cara membandingkan hasil penilaian surat dinas pada Siklus I dan hasil penilaian surat dinas pada Siklus II.

Pada Siklus I masih ada 6 siswa yang mendapatkan nilai 50, sedangkan pada Siklus II ada 6 siswa yang mendapatkan nilai 50. Pada Siklus I siswa yang mendapat nilai di bawah KKM sebesar 70 masih cukup banyak yaitu 13 anak. Pada Siklus II siswa yang mendapat nilai di bawah KKM ada. 4 siswa. Siswa yang telah tuntas pada Siklus I sebanyak 17 anak. Sedangkan pada Siklus II yang telah tuntas sebanyak 25 anak. Dapat dinyatakan bahwa telah terjadi peningkatan hasil penilaian terhadap pembelajaran IPS. Jumlah siswa yang tuntas belajar dalam IPS dari 17 anak meningkat menjadi 25 anak.

\section{KESIMPULAN}

Hasil evaluasi pada Siklus I menunjukkan bahwa penguasaan siswa terhadap kompetesi dasar Materi Aktivitas Manusia Dalam Memenuhi Kebutuhan masih kurang karena siswa yang tuntas belajar dengan mendapatkan nilai sama atau lebih besar daripada KKM (64) sebanyak 17 anak (58,62\%). Nilai rata-rata siswa dalam Materi Aktivitas Manusia Dalam Memenuhi Kebutuhan sudah lebih kecil daripada KKM 70 yaitu sebesar $(58,62 \%)$. Sedangkan hasil evaluasi pada Siklus II menunjukkan bahwa penguasaan siswa terhadap kompetensi Materi Aktivitas Manusia Dalam Memenuhi Kebutuhan sudah baik karena siswa yang tuntas belajar dengan mendapatkan nilai sama atau lebih besar daripada KKM (70) sebanyak 25 anak (100\%). Nilai rata-rata siswa pada Siklus II ini sebesar 86,26. Hal itu berarti bahwa Pembelajaran Aktivitas Manusia Dalam Memenuhi Kebutuhan Melalui Model Pembelajaran Jigsaw dapat Meningkatkan kemanpuan Siswa Kelas VII Semester II Tahun Pelajaran 2017/ 2018 di SMP Negeri 2 Gandusari Trenggalek.

\section{SARAN}

(1) Guru sebaiknya menciptakan suasana belajar yang kondusif sehingga siswa dapat belajar secara aktif, kreatif, efektif, inovatif, menyenangkan. (2) Guru harus pandai memilih strategi pembelajaran yang sesuai dengan bahan ajar dan kompetensi dasar yang akan dicapai dalam pembelajaran. (3) Guru hendaknya mampu meminimalkan dominasi dalam proses pembelajaran dan mengoptimalkan aktivitas, kreativitas dan kemampuan siswa. (4) Guru hendaknya memiliki kemauan untuk mengubah paradigma lama dalam pembelajaran dari guru sebagai pusat informasi menjadi guru sebagai fasilitator terjadinya arus informasi dalam kelas yang dikelolanya.

\section{DAFTAR RUJUKAN}

Arikunto, S., dkk. 2012. Penelitian Tindakan Kelas. Jakarta: PT. Bumi Aksara. 
Vol. 2 No. 4, Oktober 2018;

Departemen Pendidikan Nasional. 2006. Standar Kompetensi dan Kompetensi Dasar Tingkat SMP dan MTs. Jakarta: Binatama Raya.

Dimyati., \& Mudjiono. 2006. Belajar dan Pembelajaran. Jakarta: PT Rineka Cipta.

Kusnandar. 2010. Langkah Mudah Penelitian Tindakan Kelas sebagai Pengembangan Profesi. Jakarta: PT Raja Grafindo Persada.

Sudjana, Nana. 2009. Media Pengajaran. Bandung: Sinar Baru Algensindo.

Sudijono. 1991. Pengantar Statistik Pendidikan. Jakarta: PT Rajawali Pers Persada.

Sardiman. 2011. Interaksi dan Motivasi Belajar Mengajar. Jakarta: Raja Grafindo Persada.

Sugiyono. 2013. Metode Penelitian Pendidikan Pendekatan Kuantitatif, Kualitatif dan $R \& D$. Bandung: Alfabeta.

Trianto. 2010. Mendesain Model Pembelajaran Inovatif dan Progesif. Jakarta: Kencana.

Winarno. 2011. Metode Penelitian Malang: Media Cakrawala Utama Press. 